\title{
Fatty acid composition of meat and adipose tissue from Krškopolje pigs and commercial fatteners in Slovenia
}

\author{
MARJETA FURMAN, ŠPELA MALOVRH, ALENKA LEVART and MILENA KOVAČ \\ Department of Animal Science, Biotechnical Faculty, University of Ljubljana, Ljubljana, Slovenia
}

\section{Abstract}

The fatty acid composition of meat and subcutaneous adipose tissue of the indigenous Slovenian pig breed (Krškopolje, KP), which is raised extensively, was compared with that of commercial fatteners (CP) from intensive farms. Commercial fatteners were divided into three groups according to lean meat percentage: meaty, normal and fatty. The $m$. longissimus dorsi of Krškopolje pigs contained less C18:0 fatty acids than that of commercial fatteners and less C16:0 than that of the fatty group. The proportions of long chain fatty acids C20:4n-6, C20:5n-3 and C22:5n-3 in the Krškopolje pigs and fatty groups were also significantly different. The highest proportion of essential C18:2n-6 and C18:3n-3 fatty acids were found in the meaty and normal groups. Intramuscular fat content of the $m$. longissimus dorsi did not differ between the Krškopolje pigs, and the fatty and normal groups. The Krškopolje pigs had the lowest proportion of saturated fatty acids (SFAs), while both the Krškopolje pigs and the fatty group have a lower proportion of polysaturated fatty acids (PUFAs) than the meaty group. The fatty group had a lower polyunsaturated:saturated fatty acid ratio than the meaty and normal groups. In the subcutaneous adipose tissue, Krškopolje pigs had the highest proportion of C18:1 n-9 and differed from the normal group in C18:0 content, from the fatty group in C16:1 n-7 and from the meaty and fatty groups in C18:2n-6. Furthermore, the Krškopolje pigs had the highest monounsaturated fatty acids (MUFAs), and lower PUFAs and $n-6$ PUFAs proportions than the fatty group. The meaty group had a higher n-6:n-3 PUFA ratio than the Krškopolje pigs.

Keywords: pig, fatty acid composition, meat, fatness, indigenous breed, Krškopolje pig

\section{Zusammenfassung}

\section{Fettsäurezusammensetzung des Fleisch- und Fettgewebes bei Krškopolje und kommerziellen Mastschweinen in Slowenien}

Untersucht wurde die Fettsäurezusammensetzung von Fleisch- und Fettgewebe bei bodenständigen Krskopolje Schweinen (KP) naturnaher Haltung und intensiv gehaltenen kommerziellen Mastschweinen (CP). Die kommerziellen Schweine wurden entsprechend des Fleischanteils im Schlachtkörper in drei Gruppen (1=fleischreich, 2=normal, 3=fettreich) eingeteilt. KP wiesen gegenüber allen CP Gruppen im M. longissimus dorsi weniger C18:0 und weniger C16:0 Anteile gegenüber CP3 auf. Der Anteil langkettiger Fettsäuren C20:4n-6, C20:5n-3 und C22:5n-3 war unterschiedlich zwischen KP und CP3. 
Die größten Anteile essentieller C18:2n-6 und C18:3n-3 Fettsäuren fanden sich bei CP1 und CP2. Keine Unterschiede wurden im intramuskulären Fettgehalt des $M$. longissimus dorsi zwischen KP, CP2 und CP3 gefunden. KP wiesen den geringsten Gehalt gesättigter Fettsäuren auf. Im gleichen Muskel erreichte die CP1 Gruppe höhere PUFA Anteile als KP und CP3, während CP3 ein engeres Verhältnis mehrfach ungesättigter:gesättigter Fettsäuren als CP1 und CP3 zeigte. Im subkutanen Fettgewebe fand sich bei KP der höchsten C18:1 n-9 Anteil. KP unterschied von CP2 im C18:0, von CP3 im C16:1-7 und von CP1 und CP3 im C18:2n-6 Anteil. KP Tiere hatten den größten MUFA- und kleineren PUFAsowie n-6-PUFA-Anteil als CP3. Die CPI Gruppe erreichte ein weiteres n-6:n-3 PUFA Verhältnis als KP Tiere.

Schlüsselwörter: Schwein, Fettsäurezusammensetzung, Fleisch, Fettgewebe bodenständige Rasse, Krškopolje Schwein

\section{Introduction}

Fatty acid composition is an important factor in the nutritional quality of muscle and adipose tissue and as such has long been a subject of study in meat science receiving considerable attention due to its important role in human health (PFEUFFER 2001, RAES et al. 2004). According to the World Health Organisation (WHO 2003) recommendations for daily consumption, total fat should represent no more than $15-30 \%$ of total energy intake, and be comprised of less than 10\% saturated fatty acids (SFAs) and between 6 and $10 \%$ polyunsaturated fatty acids (PUFAs). Furthermore, the WHO (2003) has recommended consumption of $5-8 \%$ of $n-6$ PUFA, $1-2 \% n-3$ PUFA and no more than $1 \%$ trans fatty acids. SCOLAN et al. (2006) recommended that the n-6:n-3 PUFA ratio be limited to $4: 1$. ULBRICHT and SOUTHGATE (1991) suggested that the ratio of PUFA to SFA $(P: S)$ should be at least 0.4 and the atherogenic index lower than 0.5 . Unfortunately, the recommended $\mathrm{P}: S$ ratio for nutritional purposes is contrary to that used for processing, where a low $\mathrm{P}: \mathrm{S}$ ratio improves most technological quality parameters of muscle and adipose tissue (REICHARDT et al. 2003).

The fatty acid composition of pig muscle and adipose tissue is affected by several factors including fatness, body weight (FISCHER et al. 2006), age, energy intake and dietary fatty acid composition (PANELLA-RIERA and NEIL 2007, VÁCLAVKOVÁ and BEČKOVÁ 2007, MISSOTTEN et al. 2008). There are also factors connected to gender (BIEDERMANN et al. 2000), de novo synthesis of fatty acids (LEIBETSEDER 1996) and genetic background (KUHN et al. 1998, WOOD et al. 2003, GLODEK et al. 2004, VOLK et al. 2004, KASPRZYK 2007). Deposition and composition of fat are highly heritable and vary among and within breeds (SELLIER 1998, KASPRZYK 2007). Reducing carcass fatness was one of the major breeding goals in pigs for many years. It is likely to be accompanied by lower intramuscular fat levels (DE SMET et al. 2004), but considerable variability was still observed in intramuscular fat content within breeds independent of carcass fatness (EDNER 1994). Negative consequences of reduced fat content could be lessened by optimal breeding for meat quality traits.

The Slovenian indigenous Krškopolje pig (KP) is black, with white unbroken belt over the shoulders and down to both front feet (Figure 1). It has an average fertility, good 
growth ability and relatively high losses (ŠALEHAR 1994) under the extensive rearing conditions. KP was neglected from 1971 onwards (ŠALEHAR 1991) and was on the verge of disappearance in 1990 when breed reconstruction began by increasing the population size and setting up a breeding program. There was some uncontrolled integration of other breeds used for mating due to low number of sires (ŠALEHAR 1994). German Saddleback was introduced in 2003 in order to reduce the high risk of inbreeding. Latter on, the breeding has focused on the elimination of undesired characteristics of other breeds. Production traits of KP were studied prior to neglect period (FERJAN 1969, EISELT 1971). Since the revival of this breed, ČANDEK-POTOKAR et al. (2003) have compared the carcass traits as well as the technological and sensorial quality of KP with its cross with a modern landrace line - LN 55. However, the composition of KP meat has not yet been investigated.

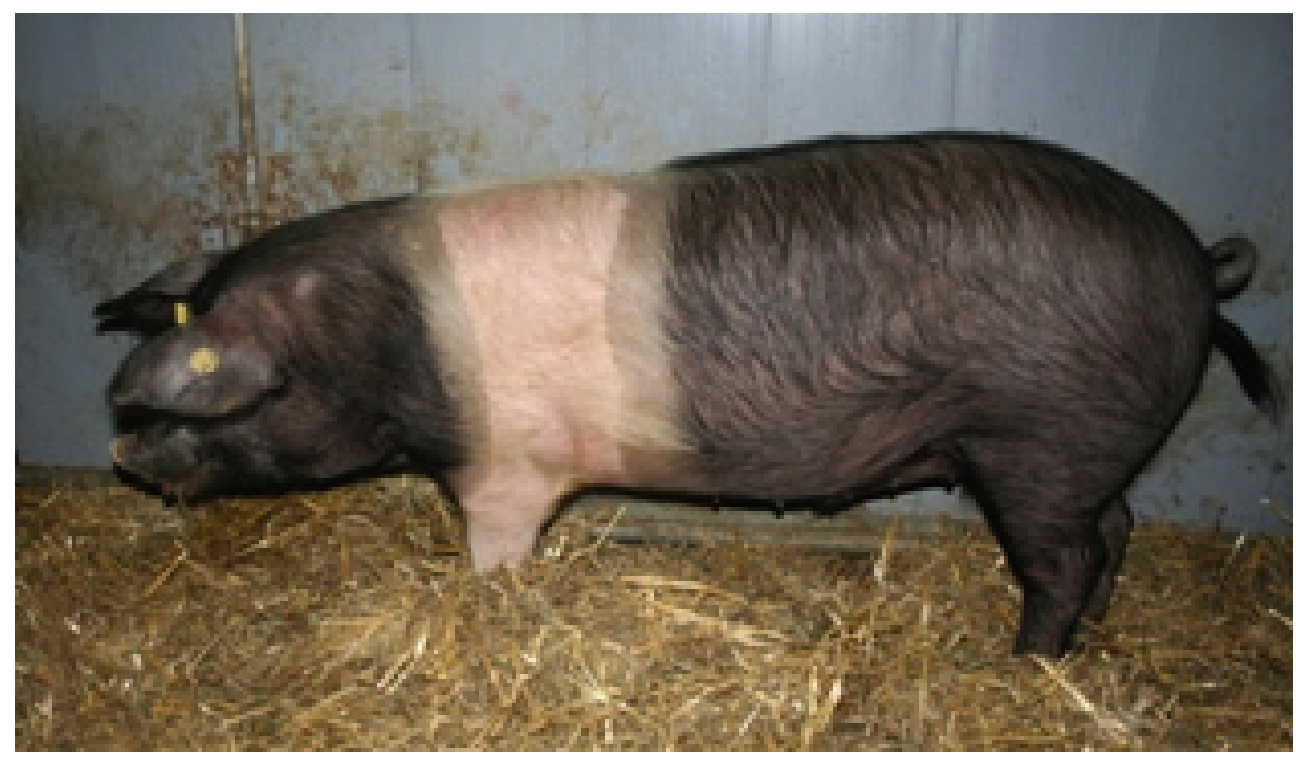

Figure 1

Krškopolje pig

Krškopolje Schwein

The objective of this study was to compare the fatty acid composition of m. longissimus dorsi and subcutaneous adipose tissue from the indigenous KP breed and commercial fatteners in Slovenia.

\section{Material and methods}

\section{Animals}

Ten KP and 43 commercial fatteners classified according to lean meat content (14 fatty, 15 normal, and 14 meaty) were obtained from industrial farms. The commercial pigs in Slovenia were mainly offspring of maternal hybrid Large White $\times$ Slovenian Landrace (line 11) mated by Pietrain, Duroc or Piertain $\times$ Slovenian Landrace (line 55) sires. The genotype of individual pig is not known because they were randomly selected on the slaughter line. Methods of 
production used to raise the pigs were typical for those of the two breeds. The KP were raised on an organic farm, reared outdoors in a barren environment and fed mainly with by-products of organic grain production. Diet changed frequently over time but neither quantity nor composition were measured. Pigs were slaughtered at age 11-12 months. Commercial fatteners were raised on conventional, intensive farms. The diet and feeding regime were those of standard practice on pig production units in Slovenia. Fatteners were assigned to three groups on the basis of lean meat content. Within each group, animals were selected among all carcasses available at the time of sampling. The slaughter age of the commercial fatteners was 6-7 months. Carcass traits for all animals were measured using the standard Slovenian on-line grading system at slaughter (OJEU 2005).

\section{Samples}

After overnight chilling of the carcasses, samples of $m$. longissimus dorsi and adjacent subcutaneous adipose tissue (backfat) were taken at the last rib, vacuum packaged and stored frozen at $-21{ }^{\circ} \mathrm{C}$. The frozen samples were cut into small pieces and dipped into liquid nitrogen $\left(\mathrm{T}=-196^{\circ} \mathrm{C}\right)$. Samples were homogenised with a blender (Grindomix, $10 \mathrm{~s}$ ), ensuring the sample temperature did not rise above $-2^{\circ} \mathrm{C}$, packaged in sealed polyethylene bags, and stored at $-21^{\circ} \mathrm{C}$ until used for chemical analysis.

\section{Lipid analyses}

Intramuscular fat (IMF) content in muscle samples was determined by the Weibull-Stoldt method (AOAC 1997). Lipids were extracted from intramuscular fat after acid hydrolysis of the samples using Soxhlet extraction with petroleum ether, followed by the gravimetric determination of dried extract.

Fatty acids from $m$. longissimus dorsi and adipose tissue were detected as their methyl esters (FAME's) according to PARK and GOINS (1994). Separation of FAME was performed by gas chromatography using an Agilent 6890 series GC (Agilent Technologies, Wilmington, DE, USA) equipped with an Agilent 7683 Automatic Liquid Sampler, a split injector, a flame-ionization detector and a fused silica capillary column OMEGAWAX (Supelco, $30 \mathrm{~m} \times 0.32 \mathrm{~mm}$ i.d.). Agilent GC ChemStation was used for data acquisition and processing. Separated FAME's were identified by retention time. The fatty acid composition was calculated using response factors derived from chromatographic standards of known composition (NuChek Prep, Elysian, MN, USA). Results are expressed as a percentage of the total fatty acids. The atherogenic index was calculated using the formula of ULBRICHT and SOUTHGATE (1991).

\section{Statistical analysis}

The statistical model included the group as class effect:

$$
y_{i j}=\mu+G_{i}+b\left(x_{i j}-\bar{x}\right)+e_{i j}
$$

where $y_{i j}$ is the observation value of the trait, $\mu$ is the overall mean, $G_{i}$ is the group class effect with four levels, $b$ is the linear regression coefficient, $x_{i j}$ is the carcass weight included as covariable, $\bar{x}$ is the mean carcass weight, and $e_{i j}$ is the random error. 
Adjustment for C20:5n-3 and n-6:n-3 PUFA in m. longissimus dorsi and C18:0 and SFA in subcutaneous adipose tissue was done within the group:

$$
y_{i j}=\mu+G_{i}+b_{i}\left(x_{i j}-\bar{x}\right)+e_{i j}
$$

where $b_{i}$ denote the linear regression coefficient nested within the group.

Differences between least square means were tested with the Tukey multiple test. Statistical analysis was carried out using the GLM procedure in SAS/STAT (SAS Institute Inc. 2001).

\section{Results and discussion}

\section{Carcass traits}

The average warm carcass weight varied from $82.5 \mathrm{~kg}$ in the meaty group to $93.3 \mathrm{~kg}$ in $\mathrm{KP}$ (Table1). The carcass weights of the KP and fatty groups were similar. Lean meat percentage (EU reference dissection method, WALSTRA and MERKUS 1995) was $47.8 \%$ in $\mathrm{KP}$, and $51.3 \%, 57.9 \%$ and $64.0 \%$ in the fatty, normal and meaty groups, respectively. Thus, the differences among groups were largely caused by variations in backfat as well as muscle thickness. The lowest lean meat content in KP was expected because the breed was reared in a barren environment. Lack of breeding is reflected in thicker backfat and thinner muscle compared to commercial pigs. Although pigs from meaty group were lighter than KP, they have a $15 \mathrm{~mm}$ thicker muscle, and only one third of the backfat thickness. The carcass weights of KP pigs were similar to those of the fatty group, however, the carcass traits describing body composition were in favour of the fatty group.

Table 1

Carcass traits in experimental groups of pigs

Schlachthälftenmerkmale der Untersuchungsgruppen

\begin{tabular}{lcccc}
\hline Variable & $\mathrm{KP}, \mathrm{n}=10$ & Fatty, $\mathrm{n}=14$ & Normal, $\mathrm{n}=15$ & Meaty, $\mathrm{n}=14$ \\
& $\overline{\mathrm{x}} \pm \mathrm{SD}$ & $\overline{\mathrm{x}} \pm \mathrm{SD}$ & $\overline{\mathrm{x}} \pm \mathrm{SD}$ & $\overline{\mathrm{x}} \pm \mathrm{SD}$ \\
\hline Carcass weight, $\mathrm{kg}$ & $93.3 \pm 12.8$ & $92.9 \pm 11.1$ & $88.3 \pm 13.2$ & $82.5 \pm 9.4$ \\
Backfat thickness, $\mathrm{mm}$ & $33.0 \pm 7.0$ & $24.0 \pm 5.0$ & $16.0 \pm 5.0$ & $10.0 \pm 2.0$ \\
Muscle thickness, $\mathrm{mm}$ & $61.0 \pm 5.0$ & $67.0 \pm 7.0$ & $72.0 \pm 8.0$ & $76.0 \pm 9.0$ \\
Lean meat, \% & $47.8 \pm 2.5$ & $51.3 \pm 2.4$ & $57.9 \pm 4.0$ & $64.0 \pm 3.2$ \\
\hline
\end{tabular}

$\overline{\mathrm{x}}$ means, SD standard deviations

\section{Intramuscular fat content}

The KP and fatty groups contained around $2 \%$ IMF in $m$. longissimus dorsi (Table 2). The lowest content of IMF (1.4\%) was observed in the meaty group. There were no differences in IMF between the KP and the fatty and normal groups. KUHN et al. $(1997,1998)$ compared a local German breed, the German Saddle Back with commercial Landrace pigs, finding that the former had twice the IMF content of the latter. Indigenous breeds are known to have a higher capacity for lipid deposition and are expected to have higher IMF (KUHN et al. 1997). 
Table 2

Fatty acid composition (LSQ means) of IMF from $m$. longissimus dorsi

Fettsäurezusammensetzung (LSQ Mittelwerte) des intramuskulären Fettes im M. longissimus dorsi

\begin{tabular}{lrrrrrr}
\hline & \multicolumn{1}{c}{$P$} & KP & Fatty & Normal & Meaty & SE \\
\hline IMF, \% & 0.0462 & $1.96^{\mathrm{a}}$ & $1.94^{\mathrm{a}}$ & $1.70^{\mathrm{ab}}$ & $1.40^{\mathrm{b}}$ & 0.15 \\
Fatty acids, g/100 g FAME & & & & & & \\
C14:0 myristic & 0.0098 & $1.17^{\mathrm{ab}}$ & $1.31^{\mathrm{a}}$ & $1.22^{\mathrm{ab}}$ & $1.14^{\mathrm{b}}$ & 0.04 \\
C16:0 palmitic & $<0.0001$ & $21.76^{\mathrm{a}}$ & $23.97^{\mathrm{b}}$ & $22.56^{\mathrm{a}}$ & $21.81^{\mathrm{a}}$ & 0.33 \\
C18:0 stearic & $<0.0001$ & $10.14^{\mathrm{a}}$ & $12.13^{\mathrm{b}}$ & $11.49^{\mathrm{b}}$ & $11.65^{\mathrm{b}}$ & 0.21 \\
C16:1n-7 palmitoleic & $<0.0001$ & $4.08^{\mathrm{a}}$ & $3.66^{\mathrm{ab}}$ & $3.23^{\mathrm{bc}}$ & $3.07^{\mathrm{c}}$ & 0.14 \\
C18:1n-9 oleic & 0.0002 & $43.27^{\mathrm{a}}$ & $41.58^{\mathrm{ab}}$ & $40.21^{\mathrm{bc}}$ & $37.74^{\mathrm{c}}$ & 0.87 \\
C18:2n-6 linoleic & 0.0005 & $11.28^{\mathrm{a}}$ & $10.36^{\mathrm{a}}$ & $12.75^{\mathrm{ab}}$ & $14.66^{\mathrm{b}}$ & 0.80 \\
C18:3n-3 a-linolenic & 0.0183 & $0.32^{\mathrm{ab}}$ & $0.27^{\mathrm{b}}$ & $0.39^{\mathrm{ab}}$ & $0.42^{\mathrm{a}}$ & 0.04 \\
C20:4n-6 arahidonic & $<0.0001$ & $3.86^{\mathrm{ab}}$ & $2.86^{\mathrm{c}}$ & $3.62^{\mathrm{bc}}$ & $4.68^{\mathrm{a}}$ & 0.28 \\
C20:5n-3 eicosapentaenoic & 0.0002 & $0.13^{\mathrm{ab}}$ & $0.09^{\mathrm{c}}$ & $0.12^{\mathrm{bc}}$ & $0.16^{\mathrm{a}}$ & 0.01 \\
C22:5n-3 docosapentaenoic & 0.0004 & $0.49^{\mathrm{a}}$ & $0.32^{\mathrm{b}}$ & $0.44^{\mathrm{ab}}$ & $0.57^{\mathrm{a}}$ & 0.05 \\
C22:6n-3 docosahexaenoic & $<0.0004$ & $0.10^{\mathrm{a}}$ & $0.08^{\mathrm{a}}$ & $0.11^{\mathrm{a}}$ & $0.16^{\mathrm{b}}$ & 0.01 \\
SFA & $<0.0001$ & $33.82^{\mathrm{a}}$ & $38.30^{\mathrm{b}}$ & $36.20^{\mathrm{c}}$ & $35.53^{\mathrm{c}}$ & 0.47 \\
MUFA & $<0.0001$ & $48.55^{\mathrm{a}}$ & $46.36^{\mathrm{ab}}$ & $44.57^{\mathrm{bc}}$ & $41.93^{\mathrm{c}}$ & 0.99 \\
PUFA & 0.0001 & $17.61^{\mathrm{ab}}$ & $15.33^{\mathrm{a}}$ & $19.09^{\mathrm{bc}}$ & $22.56^{\mathrm{c}}$ & 1.17 \\
$\mathrm{n}-6$ PUFA & 0.0001 & $16.39^{\mathrm{ab}}$ & $14.41^{\mathrm{c}}$ & $17.85^{\mathrm{bc}}$ & $21.07^{\mathrm{c}}$ & 1.09 \\
$\mathrm{n}-3$ PUFA & 0.0007 & $1.13^{\mathrm{ab}}$ & $0.84^{\mathrm{b}}$ & $1.16^{\mathrm{ab}}$ & $1.40^{\mathrm{a}}$ & 0.11 \\
Indices & & & & & & \\
n-6:n-3 PUFA & & & & & & \\
P:S & 0.0531 & 14.33 & 17.03 & 16.12 & 14.94 & 0.90 \\
Atherogenic index & $<0.0001$ & $0.52^{\mathrm{ab}}$ & $0.40^{\mathrm{b}}$ & $0.53^{\mathrm{a}}$ & $0.64^{\mathrm{a}}$ & 0.04 \\
\hline
\end{tabular}

${ }^{1}$ model 2 was used, SE standard error, $\quad{ }^{a, b}$ values signed with different superscripts are significantly different $(P<0.05)$

\section{Fatty acid composition of IMF in m. longissimus dorsi}

The IMF of the fatty group contained more SFA acids than that of the other groups (Table 2). Commercial pigs with low lean meat content (Table 1) contained the largest proportion of palmitic fatty acid (C16:0). The KP meat contained the lowest proportion of stearic (C18:0) and palmitic (C16:0) acids making it more healthy for human consumption than that of the commercial groups despite being the fattiest pigs, with IMF content similar to the fatty group (Table 1). Myristic acid content (C14:0) was significantly greater in the meaty than the fatty group, but no significant differences were observed between the commercial and KP pigs. These findings are in contrast to those of DE SMET et al. (2004) who found that saturated fatty acids decreased with decreasing meatiness, but are similar to trends in C14:0 and C18:0 content observed by KOUBA et al. (2003) who found larger proportions in heavier pigs in the control group as well as in the group with linseed supplement.

Content of the two major monounsaturated fatty acids (oleic and palmitoleic acids) increased with increasing fattiness and was the highest in the KP and fatty groups and the lowest in the meaty group. KOUBA et al. (2003) found similar trends in C16:1n-7 and C18:1n-9 in longissimus muscle with the increasing age and fattiness of pigs.

The greatest proportion of PUFA was observed in the meaty group and decreased with fattiness in commercial pigs (Table 2); the proportion of PUFA in KP was not 
significantly different from that in the normal and fatty groups. The commercial groups had the same diets and ages at slaughter suggesting that the increase of PUFA is related mainly to the leanness of the animal. Lower proportions of PUFA are desirable technologically. Traditionally, KP were used for home consumption and slaughter was performed mainly during the winter. Meat was dried and stored in aerated premises or fresh-stored in minced lard for one year or more, so a good technological quality of the meat was required to maintain good sensory quality with minimal fat oxidation.

The greatest proportions of the two essential fatty acids, linoleic (C18:2n-6) and alinolenic (C18:3n-3), were found in the meaty group and the lowest in the fatty. KOUBA et al. (2003) observed a similar decrease in C18:3n-3 but found an increase in C18:2n-6 with fattiness. Although the KP were the fattiest animals and had an IMF content similar to that of the fatty group, the content of long chain fatty acids (C20-22) more closely resembled that of the normal and meaty groups than the fatty group. In the commercial pigs, the meaty group had a higher content of C20-22 than the fatty. A similar decrease in minor C20-C22 acids was found by KOUBA et al. (2003).

The proportions of SFA increased with increasing fattiness of the commercial pigs, but were significantly higher than in the KP. The greatest proportions of MUFA were found in both the KP and the fatty groups. The proportion of MUFA in KP was significantly different from that in the meaty and normal groups. The KP pigs show a desirable proportion of MUFA from both nutritional and technological points of view and deviate from the generally accepted view that meat from fattier pigs contains more saturated than unsaturated fatty acids (DE SMET et al. 2004).

\section{Fatty acid composition of adipose tissue}

The fatty acid composition in subcutaneous adipose tissue (Table 3) differed less among groups than in the IMF of $m$. longissimus dorsi. The KP contained a lower proportion of C18:0 (11.54\%) than the normal group (13.14\%), but was not different from the meaty or fatty groups. The proportion of saturated fatty acids was lower in KP than in the normal group. Both major monounsaturated fatty acids (C16:1n-7 and C18:1n-9) contents were the highest in KP at $2.4 \%$ and $46.6 \%$ respectively. These results are similar to those of WOOD et al. (1989) who showed that the levels of C16:0, C18:0 and C18:1n-9 increased with thicker subcutaneous adipose tissue in pigs. PASCUAL et al. (2006) also observed higher contents of C18:0 and C18:1n-9 in the adipose tissue of heavier pigs having between 15 and $80 \mathrm{~kg}$ body weight. However, these authors did not find a significant correlation between weight and C16:0 content. Higher weight and fatness were related to a higher de novo synthesis of C18:0 and C18:1n-9 in subcutaneous adipose tissue. In another study, FISCHER et al. (2006) analysed fatty acid profile in the outer layer of backfat adipose tissue in pigs associated with prolonged fattening $(110,135$ and $160 \mathrm{~kg}$ slaughter weights). The highest proportions of C14:0, C16:0 and C18:1n-9 were found only in heavier gilts, but there were no differences in C18:0 and C16:1n-7 with weight. Similar results for $\mathrm{C} 18: 0$ and $\mathrm{C} 16: 1 \mathrm{n}-7$ were found in the present experiment (Table 3), but there were also no differences in C14:0, C16:0 and C18:1n-9 among commercial fatteners. 
Table 3

Fatty acid composition (LSQ means) of subcutaneous adipose tissue Fettsäurezusammensetzung (LSQ Mittelwerte) im subkutanen Fettgewebe

\begin{tabular}{llccccc}
\hline & $P$ & KP & Fatty & Normal & Meaty & SE \\
\hline Fatty acids, g/100 g FAME & & & & & & \\
C14:0 myristic & 0.1784 & 1.24 & 1.33 & 1.29 & 1.34 & 0.04 \\
C16:0 palmitic & 0.4382 & 22.67 & 23.45 & 23.88 & 23.66 & 0.58 \\
C18:0 $\quad$ stearic & 0.0205 & $11.54^{\mathrm{a}}$ & $12.95^{\mathrm{ab}}$ & $13.14^{\mathrm{b}}$ & $12.27^{\mathrm{ab}}$ & 0.43 \\
C16:1n-7 palmitoleic & 0.0423 & $2.40^{\mathrm{a}}$ & $2.02^{\mathrm{b}}$ & $2.18^{\mathrm{ab}}$ & $2.15^{\mathrm{ab}}$ & 0.10 \\
C18:1n-9 oleic & $<0.0001$ & $46.61^{\mathrm{a}}$ & $39.88^{\mathrm{b}}$ & $41.04^{\mathrm{b}}$ & $40.32^{\mathrm{b}}$ & 0.78 \\
C18:2n-6 linoleic & 0.0231 & $10.54^{\mathrm{a}}$ & $15.33^{\mathrm{b}}$ & $13.70^{\mathrm{ab}}$ & $14.70^{\mathrm{b}}$ & 1.22 \\
C18:3n-3 a-linolenic & 0.1702 & 0.67 & 0.91 & 0.81 & 0.73 & 0.10 \\
C20:4n-6 arahidonic & 0.0813 & 0.22 & 0.28 & 0.26 & 0.30 & 0.03 \\
C20:5n-3 eicosapentaenoic & 0.9699 & 0.02 & 0.01 & 0.01 & 0.01 & 0.002 \\
C22:5n-3 docosapentaenoic & 0.7000 & 0.09 & 0.09 & 0.09 & 0.08 & 0.01 \\
C22:6n-3 docosahexaenoic & 0.1726 & 0.02 & 0.03 & 0.02 & 0.02 & 0.003 \\
SFA2 & 0.0781 & 36.13 & 38.48 & 39.24 & 37.63 & 0.97 \\
MUFA & $<0.0001$ & $50.81^{\mathrm{a}}$ & $43.35^{\mathrm{b}}$ & $44.70^{\mathrm{b}}$ & $43.96^{\mathrm{b}}$ & 0.85 \\
PUFA & 0.0403 & $12.72^{\mathrm{a}}$ & $17.85^{\mathrm{b}}$ & $16.05^{\mathrm{ab}}$ & $17.02^{\mathrm{ab}}$ & 1.40 \\
n-6 PUFA & 0.0289 & $11.64^{\mathrm{a}}$ & $16.56^{\mathrm{b}}$ & $14.85^{\mathrm{ab}}$ & $15.90^{\mathrm{ab}}$ & 1.29 \\
n-3 PUFA & 0.5974 & 0.97 & 1.19 & 1.08 & 0.97 & 0.12 \\
Indices & & & & & & \\
n-6:n-3 PUFA & 0.0087 & $12.09^{\mathrm{a}}$ & $14.86^{\mathrm{ab}}$ & $14.77^{\mathrm{ab}}$ & $16.56^{\mathrm{b}}$ & 0.93 \\
P:S & 0.2522 & 0.35 & 0.47 & 0.42 & 0.44 & 0.05 \\
Atherogenic index & 0.2648 & 0.44 & 0.47 & 0.48 & 0.48 & 0.02 \\
\hline
\end{tabular}

${ }^{1}$ model 2 was used, SE standard error, values signed with different superscripts are significantly different $(P<0.05)$

The proportion of essential fatty acid C18:2n-6 was the lowest in KP (10.54\%, Table 3), while $\mathrm{C} 18: 3 n-3$ content did not differ among the groups. There were no differences in C18:2n- 6 content among commercial groups, in contrast to the observations of DE SMET et al. (2004) who found that fattier pigs contained less PUFA in subcutaneous adipose tissue. The KP contained $4.79 \%$ less $\mathrm{C} 18: 2 \mathrm{n}-6$ in adipose tissue than the fatty group and $4.16 \%$ less than in the meaty group. WOOD et al. (1989) and FISCHER et al. (2006) observed the highest contents of $\mathrm{C} 18: 2 \mathrm{n}-6$ and $\mathrm{C} 18: 3 \mathrm{n}-3$ in leaner and lighter pigs. In addition, PASCUAL et al. (2006) showed a negative correlation between C18:2n-6 content and carcass weight. WOOD et al. $(1999,2003)$ suggested that if the level of C18:2n-6 exceeds $15 \%$ of total fatty acids in subcutaneous adipose tissue and C18:3n-3 approaches $3 \%$, then soft fat is produced with a high probability of lipid oxidation, affecting shelf-life and flavour. While all the groups studied here should produce a good quality fat, these criteria suggest that the adipose tissue of the KP is firmer and less prone to oxidation than that of the three commercial groups.

Long chain PUFAs were detected in smaller quantities than in the IMF and there were no significant differences among the groups (Table 3). WOOD et al. (2003) also found that the long chain n-3 PUFA (C20-C22) were at low but detectable levels in pork subcutaneous fat. Other authors have observed differences in PUFA content. FISCHER et al. (2006) found a higher content of C20:4n-6 in the subcutaneous fat of gilts. Furthermore, KOUBA et al. (2003) observed decreasing percentages of C20:5n-3, C22:5n-3 and C22:6n-3 with duration of fattening, which was related to an increased carcass fatness. 
The proportion of essential linoleic acid (C18:2n-6) in the commercial groups was lower in $m$. longissimus dorsi (Table 2) than in adipose tissue (Table 3), which is in agreement with results by KOUBA et al. (2003) and TEYE et al. (2006). However, the opposite was observed in KP with greater proportions of $\mathrm{C} 18: 2 \mathrm{n}-6$ in muscle $(11.28 \%)$ than in adipose tissue (10.54\%) which more closely resembles the findings of ENSER (1996) who found similar proportions in both tissues: $14.2 \%$ in muscle and $14.3 \%$ in adipose tissue. The proportion of the essential a-linolenic acid (C18:3n-3) was higher in subcutaneous adipose tissue of KP $(0.67 \%$; Table 3$)$ than in muscle tissue $(0.32 \%$; Table 2$)$. Higher proportions were also observed among the commercial groups. The contents were lower than determined by ENSER et al. (1996) who found $1.43 \%$ of C18:3n-3 in pig adipose tissue and $0.95 \%$ in muscle of pork loin chops. Differences could be a consequence of diet composition as the major influence for C18:3n-3 content in meat. Moreover, KOUBA et al. (2003) and WOOD et al. (2008) observed a higher proportion of C18:3n-3 in subcutaneous adipose than in muscle tissue which is in agreement with the present results.

There were more long chain PUFAs (C20-C22) in muscle (Table 2) than in subcutaneous adipose tissue (Table 3 ) in all the groups. Muscle contains a significant proportion of C20-22 PUFA (WOOD et al. 2008) which are formed from C18:2n- 6 and C18:3n-3 by the action of desaturase and elongase enzymes. Important products are arahidonic (C20:4n6) and eicosapentaenoic (C20:5n-3) acids which have various metabolic roles including eicosanoid synthesis. Greater proportions of C20:4n-6 were observed in muscle (Table 2) than in adipose (Table 3 ) tissues because of its incorporation in phospholipids. Intramuscular fat refers to the fatty acids present in muscle tissue, and includes fat both external to and within the muscle fibres (RAES et al. 2004). Fat cells external to the muscle fibres contain mainly triacylglycerols while the lipids within the fibres consist of cytosolic droplets of triacylglycerols, phospholipids and cholesterol.

\section{Meat quality}

Generally, pigs with less fat have more unsaturated (softer) fat, whether they are leaner due to genetics, gender or nutritional factors (PETTIGREW and ESNAOLA 2001, VOLK et al. 2004). Genetically, leaner pigs usually synthesize smaller amounts of fatty acids in the tissues which causes an increased proportion of unsaturated fatty acids received from the diet. The results for the commercial pigs confirm the relationship between fattiness and fatty acid composition, but the KP did not follow the same trend. These animals were the fattiest, but had the lowest proportions of SFA and PUFA, and the greatest proportion of MUFA compared to the commercial pigs. Unfortunately, KP pigs cannot currently be reared intensively as commercial pigs because they become too fatty and therefore, the pigs in this study were reared under conditions commonly used in Slovenia for these animals. Consequently, the causal effects on fat composition in KP compared to pigs raised commercially could not be elucidated due to the confounding of several production factors including breed, feed, environment, slaughter weight and slaughter age.

In human nutrition, both the content of PUFA and the ratio between n-6 PUFA and n-3 PUFA are important. A high n-6 PUFA intake can negatively impact human health. The proportion of n-6 PUFA in muscle tissue ranged from $14 \%$ in the fatty group to $21 \%$ in the meaty. The proportion in the meaty group was also $5 \%$ greater than in KP. 
The proportion of $n-3$ PUFA was significantly higher in the meaty than the fatty group. However, the n-6:n-3 PUFA ratio did not differ among the groups. The ratio of $n-6: n-3$ PUFA in all the groups was higher than recommended (4:1) or commonly accepted for pig meat (WOOD et al. 2003, 2008). Even in KP, where the ratio had the lowest value, it was twice as much as these authors suggest for pig meat and three times the amount recommended for human nutrition. However, it should be noted that in the present experiments the meat had low $(<2 \%)$ IMF content in all the groups.

The dietary $\mathrm{P}: \mathrm{S}$ ratio and atherogenic index $(\mathrm{Al})$ are used as parameters to describe the risk of cardiovascular disease in humans. While all the $P: S$ ratios were acceptable $(\geq 0.4)$, the $\mathrm{P}: S$ ratio of $\mathrm{KP}(0.40)$ was at the lower limit of the nutritional recommendation (WHO, 2003). The P:S ratio was higher in the normal and meaty groups than in the fatty group. The ratio in KP meat was similar to that in the meaty and the normal groups. The only difference in $\mathrm{P}: \mathrm{S}$ ratios and $\mathrm{Al}$ between $\mathrm{KP}$ and commercial pigs was that of $\mathrm{Al}$ between KP (0.40) and the fatty group (0.48). The Al of all the groups was lower than 0.50 as recommended by ULBRICHT and SOUTHGATE (1991).

With lower IMF content in commercial pigs, a higher P:S ratio was observed. DE SMET et al. (2004) found higher contents of SFA and MUFA than PUFA with increasing fattiness, leading to a decrease in the $P: S$ ratio. ENSER et al. (1996) observed that pork with the highest proportion of $\mathrm{C} 18: 2 \mathrm{n}-6$ (14.2\% of total fatty acids) also had the highest $\mathrm{P}: \mathrm{S}$ ratio (0.58). A higher proportion of $C 18: 2 n-6$ and higher $P: S$ ratio were found in the meaty than in the fatty groups in the present study.

\section{Backfat quality}

The nutritional quality of subcutaneous adipose tissue is important as backfat is widely used in manufactured meat products (REICHARDT et al. 2003). In the current study, the proportion of SFA in the subcutaneous adipose tissue did not vary between the groups. The KP had the highest proportion of MUFA (50.8\%) and a lower proportion of PUFA than the fatty group. It has been suggested that an adipose tissue of good nutritional quality should contain less than $15 \%$ PUFA and more than $12 \%$ C18:2n-6 (HOUBEN and KROL, 1983). With $13 \%$ PUFA and $11 \%$ C18:2n-6, the subcutaneous adipose tissue of KP was close to fulfilling these suggested levels.

Differences among groups were also found in proportions of $n-6$ PUFA and in the $n-6: n-3$ PUFA ratio. The KP contained $5 \%$ less $n-6$ PUFA than the fatty group. The $n-6: n-3$ PUFA ratio of the meaty group was significantly higher than the KP. Furthermore, the $n-6: n-3$ PUFA ratio of all the groups exceeded the nutritional recommendation of $4: 1$ (SCOLAN et al. 2006) as was also observed in the muscle tissue. High n-6 PUFA compared to n-3 PUFA proportions in subcutaneous adipose tissue could be explained by the use of feed components rich in C18:2n-6, such us wheat and barley (SOUCl et al. 2000; VÁCLAVKOVÁ and BEČKOVÁ, 2007). C18:3n-3 is present in many feed ingredients but at lower levels than C18:2n-6 (WOOD et al. 2008). There were no differences in P:S and $\mathrm{Al}$ indices among the groups.

In conclusion, the organically raised KP had better fatty acid composition in both $m$. longissimus dorsi and subcutaneous adipose tissue compared to the fatty group of commercial pigs and it was more similar to the normal and meaty groups. Low intramuscular 
fat content and lower SFA and Al in muscle, and higher MUFA, lower PUFA and n-6 PUFA in adipose tissue were also observed in the KP than in the fatty pigs. Thus, rearing of KP has a market niche for traditional, especially durable products (dried, stored in minced lard). The greatest problem is the small population of KP despite of the enlargement of breeding stock. Furthermore, this small population is segmented into small herds, keeping pigs mainly for hobby. Consequently, the market could not be supplied with required quantities of products all the time. Crossing the KP with modern breeds could be an alternative solution. However, the approach has not been implemented yet in order to reconstruct the population and to avoid further degradation of the breeding.

\section{Acknowledgements}

The authors are grateful to Dr. Tania Ngapo from Agriculture and Agri-Food Canada for providing valuable comments on the subject and correcting the English.

\section{References}

AOAC (1997) Offical Method 991.36 Fat (Crude) in Meat and Meat Product. In: Offical method of analysis of AOAC International. 16th ed. Washington, AOAC International, 39-42

Biedermann G, Jatsch C, Peschke W, Lindner JP, Wittmann W (2000) Fattening and carcass performance and meat- and fat quality of Piétrain pigs of different MHS-genotype and sex. II. Fatty acid pattern of the adipose tissues back fat, leaf fat and intramuscular fat and of the total- and phospholipids of the M. long dorsi. Arch Tierz 43, 165-78 [in German]

Čandek-Potokar M, Žlender B, Kramar Z, Šegula B, Fazarinc G, Uršič M (2003) Evaluation of Slovene local pig breed Krškopolje for carcass and meat quality. Czech J Anim Sci 48, 120-8

De Smet S, Raes K, Demeyer D (2004) Meat fatty acid composition as affected by fatness and genetic factors: a review. Anim Res 53, 81-98

Eiselt E (1971) Productive characteristics of Krškopolje pig. Zbornik Biotehniške fakultete, Univerza v Ljubljani 18, 7-11 [in Slovenian]

Ender K (1994) Future demands on meat quality. Arch Tierz 37 Special Issue, 143-52 [in German]

Enser M, Hallett K, Hewitt B, Frusey GAJ, Wood JD (1996) Fatty acid content and composition of English beef, lamb and pork at retail. Meat Sci 42, 443-56

Ferjan J (1969) Applicability of black-belted pig breed. Sodobno kmetijstvo 2, 475-8 [in Slovenian]

Fischer K, Lindner JP, Judas M, Höreth R (2006) Carcass and meat quality of heavy pigs. II. Characteristics of meat and fat quality. Arch Tierz 49, 279-92 [in German]

Glodek P, Kratz R, Schulz E, Flachowsky G (2004) Effect of sire breeds in commercial pig crosses on growth, carcass composition, meat and fat quality. Arch Tierz 47, 59-74 [in German]

Houben JH, Krol B (1983) Pig fats and the manufacture and storage of meat products. In Fat Quality in Lean Pigs, Workshop in EEC programme, Brussels, 15-26

Kasprzyk A (2007) Characteristics of genetic parameters and genetic gain in breeding herd of PL pigs over 25-year breeding work period. Arch Tierz 50 Special Issue, 107-15

Kouba M, Enser M, Whittington FM, Nute GR, Wood JD (2003) Effect of high-linolenic acid diet on lipogenic enzyme activities, fatty acid composition, and meat quality in the growing pig. J Anim Sci 81, 1967-79

Kuhn G, Hartung M, Falkenberg H, Nürnberg G, Langhammer M, Schwerin M, Ender K (1997) Growth, carcass composition and meat quality in pigs with different capacity for lipid deposition. Arch Tierz 40, 345-55 [in German]

Kuhn G, Härtung M, Nürnberg K, Fiedler I, Falkenberg H, Nürnberg G, Ender K (1998) Body composition and muscle structure in genetically different pigs in dependence on MHS-status. Arch Tierz 41, $589-96$ [in German]

Leibetseder J (1996) Influence on the composition of animal fat by nutrition. Arch Tierz 39, 333-45 [in German]

Missorten JAM, Claeys E, Raes K, De Smet S (2008) Influence of sow dietary PUFA source on the fatty acid profile of piglet tissues and blood and on piglet performance. Arch Tierz 51 Special Issue, 32

OJEU (Official Journal of the European Union) (2005) Commission decision of 8 December 2005 authorising methods for grading pigs carcases in Slovenia. K(2005) 4744 
Panella-Riera N, Neil M (2007) Evaluation of the influence of dietary fat content and fatty acid composition in four diets based on different fat sources on loins ( $M$. longissimus dorsi) of newborn piglets. Arch Tierz 50 Special Issue, 72-8

Park PW, Goins RE (1994) In situ preparation of fatty acid methyl esters for analysis of fatty acid composition in foods. J Food Sci 59, 1262-6

Pascual JV, Rafecas M, Canela MA, Boatella J, Bou R, Baucells MD, Codony R (2006) Effect of increasing amounts of a linoleic-rich dietary fat on the fat composition of four pig breeds. Part I: Backfat fatty acid evolution. Food Chem 96, 538-48

Pettigrew JE, Esnaola MA (2001) Swine nutrition and pork quality: A review. J Anim Sci 79, 316-42

Pfeuffer M (2001) Physiologic effects of individual fatty acids in animal and human body, with particular attention to coronary heart disease risk modulation. Arch Tierz 44, 89-98

Raes K, De Smet K, Demeyer D (2004) Effect of dietary fatty acid on incorporation of long chain polyunsaturated fatty acids and conjugated linoleic acid in lamb, beef and pork meat: a review. Anim Feed Sci technol 113, 199-221

Reichardt W, Gernand E, Müller S, Härtung H, Eckert B, Braun U (2003) Examinations to the fatty acid composition of backfat at Thuringian pigs as well as to the fat of Thuringian cracking sausages from the retail trade. Arch Tierz 46, 257-267 [in German]

SAS Institute Inc (2001) The SAS System for Windows, Release 8.02. SAS Institute Inc, Cary, NC

Scollan ND, Hocquette JF, Nürnberg K, Dannenberger D, Richardson RI, Moloney A (2006), Innovations in beef production systems that enhance the nutritional and health value of beef lipids and their relationship with meat quality. Meat Sci 74, 17-33

Sellier P (1998) Genetics of meat and carcass traits. In: The genetics of the pig (eds.: Rothschild, M.F., Ruvinsky, A.). Wallingford, UK, CAB International, 463-510

Souci SW, Fachmann H, Kraut H (2000) Food composition and nutrition tables (English, German, French). CRC Press, Stuttgart, Germany

Šalehar A (1991) The remains of Krškopolje pig. Sodobno kmetijstvo 15, 234 [in Slovenian]

Šalehar A (1994) The Krškopolje pig. Pig news inf 15, 59-61

Teye GA, Sheard PR, Whittington FM, Nute GR, Stewart A, Wood JD (2006) Influence of dietary oils and protein level on pork quality. 1. Effect on muscle fatty acid composition, carcass, meat and eating quality. Meat Sci 73, 157-65

Ulbricht TLV, Southgate DAT (1991) Coronary heart disease: seven dietary factors. The Lancet 338, 985-92

Václavková E, Bečková R (2007) Effect of linseed in pig diet on meat quality and fatty acid content. Arch Tierz 50 Special Issue, 144-51

Volk B, Biedermann G, Kuhn M, Jatsch C (2004) Influence of different genetic origins on fattening and carcass performance, on quality of meat and fat as well as fatty acid pattern of phospholipids from pigs. Arch Tierz 47, 455-62 [in German]

Walstra P, Merkus GSM (1995) Procedure for assessment of the lean meat percentage as a consequence of the new EU reference dissection method in pigs carcass classification. DLO - Research Institute for Animal Science and Health (ID-DLO), Research Branch Zeist

WHO (2003) Diet, nutrition and the prevention of chronic diseases. Report of joint WHO/FAO expert consultation. WHO technical report series 916, Geneva:56

Wood JD, Enser M, Whittington FM, Moncrieff CB, Kempster AJ (1989) Backfat composition in pigs: differences between fat thickness groups and sexes. Livest Prod Sci 22, 351-62

Wood JD, Enser M, Fisher AV, Nute GR, Richardson RI, Sheard PR (1999) Manipulating meat quality and consumption. P Nutr Soc 58, 363-70

Wood JD, Richardson RI, Nute GR, Fisher AV, Campo MM, Kasapidou E, Sheard PR, Enser M (2003) Effect of fatty acids on meat quality: a review. Meat Sci 66, 21-32

Wood JD, Enser M, Fisher AV, Nute GR, Sheard PR, Richardson RI, Huges SI, Whittington FM (2008) Fat deposition, fatty acid composition and meat quality: A review. Meat Sci 78, 343-58

Received 4 May 2009, accepted 16 December 2009.

Corresponding author:

MARJETA FURMAN

email: marjeta.furman@bfro.uni-lj.si

Department of Animal Science, Biotechnical Faculty, Groblje 3, SI-1230 Domžale, Slovenia 